\title{
The Impact of Resilience to Change on the Transformational Leadership Behaviors Demonstrated by Frontline Sales Professionals
}

\author{
Mary H. Sylvester, Ph.D. \\ Capella University, Minneapolis, MN \\ 5 Debra Lane, New Milford, CT06776
}

Tel: (972) 971-9819

$\begin{array}{lrr}\text { Received: Jan.13, } 2015 & \text { Accepted: Jan. 31, } 2015 & \text { Published: January 31, } 2015 \\ \text { doi:10.5296/jmr.v7i1.6997 } & \text { URL: http://dx.doi.org/10.5296/jmr.v7i1.6997 }\end{array}$

\begin{abstract}
This study explores the impact of resilience and key demographics on the transformational leadership behaviors demonstrated by frontline sales professionals. Data were collected from a sample 356 frontline sales professionals (55\% male, $45 \%$ female, and covering both large and small industries). The sample responded to two pre-validated surveys about their transformational leadership, resilience to change, and socio-demographic profile. The analysis indicates that resilience was a positive, low to moderate predictor of transformational leadership behavior explaining $23 \%$ of the variance in the transformational leadership behaviors. This study relied on self-reported responses, which are subject to biases that may result from the research participants' capacity to recall or remember events and/or routinely demonstrated characteristics.

The data obtained in this study confirms that the level of resilience to change in frontline sales professionals predicts a portion of the level of transformational leadership behaviors demonstrated by individuals and throughout organizations of varying sizes. The current literature lacks an exploratory analysis of the relationship between resilience to change and the demonstration of transformational leadership behaviors. This study adds to the empirical literature on both topics.
\end{abstract}

Keywords: Transformational Leadership, Leadership, Resilience, Change, Frontline Sales Professionals 


\section{Introduction}

The concept of leadership has long been the focus of scientific management, academic research, and organizational application. Despite the thousands of studies, academic and organizational leaders alike continue to work to understand what leadership is and how it can be achieved and applied. Leadership in the last century focused on its different theoretical aspects leading to widespread interest and research on the associations between the behaviors of transformational leadership and higher individual, group, and organizational performance (Bass, 1996).

Transformational leadership theory evolved from the preceding leadership styles, trait and behavior theories, and charismatic, situational, and transactional leadership (Burns, 1978). Transformational leadership is the ability to get people to want to change, to improve, and to be led (Bass, 1985), creating positive change in followers whereby they take care of each other's interests and act in the interests of the group as a whole. With the transformational leadership style, the leader enhances the motivation, morale, and performance of the follower group.

This study explores whether transformational leadership behaviors are grounded in moderate to high levels of resilience to change. The five components of transformational leadership, (Challenging the Process, Modeling the Way, Inspiring a Shared Vision, Encouraging the Heart, and Enabling Others to Act) (Kouzes \& Posner, 1987) have been compared with attributes of resilience to change to assess whether the two variables are correlated. The literature, although limited, seems to point to a connection between these two concepts, though there is a lack of empirical evidence outlining this relationship present in the literature today.

An organization's ability to cultivate transformational leaders within its ranks who can rapidly and effectively adapt to change may mean the difference between the firm's survival and failure over time (Norman, Luthans \& Luthans, 2005). Individuals, organizations, and leaders must develop the skills to identify possible challenges and work disruptions, to be flexible and adaptable in a variety of situations, to focus on creatively and innovatively solving problems in evolving situations, and to stand prepared to implement solutions as rapidly as possible (Conner, 2000).To accompany turbulent changes, organizations need a new paradigm of leadership that involves everyone within an organization possessing leadership capabilities by developing a culture where everyone serves as leader collectively rather than sequentially (Raelin, 2006, p. xi). Therefore, developing transformational leaders on the front lines of an organization is vital to managing business in this century.

Leaders frequently encounter obstacles, setbacks, and challenges while dealing with the volatile, uncertain, complex, and ambiguous changes that occur in business (Harland, Harrison, Jones \& Reiter-Palmon, 2005). Resistance to change, rather than embracing and preparing for change, can result in an organization paying for both the efforts to maintain the status quo and the costs of reacting to unanticipated situations and challenges (Werther, 2003). Whether leaders encounter challenges and setbacks personally or professionally, organizations as a whole face challenging times and the way individuals, organizations, and leaders react to change is a feature of resiliency (Seeger, Ulmer, Novak \& Sellnow, 2005). Resilience is one attribute that allows an individual and an organization to maintain its original purpose, structure, and identity regardless of the constant chaos taking place in the business 
environment (Chaharbaghi, Adcroft \& Willis, 2005). In a sense, resilience allows adaptability and elasticity when responding to change, the ability to bounce back or spring forward to harness new opportunities. As a result, resilience can be thought of as a building block of transformational change for individuals, leaders, and organizations (Chaharbaghi et al., 2005). This capacity or ability to change while moving forward progressively requires both strong transformational leadership and resilient behaviors to help drive organizations into the future (Harland et al., 2005; Raelin, 2006, Bennis, 2007).

\section{Theoretical Review and Hypotheses}

The trait, behavioral, charismatic, situational, and contingency theories provided the foundation for the relational theories with each contributing toward the development of the transactional and transformational leadership theories.

\subsection{Transformational Leadership}

The relationship theories, including transactional and transformational theories of the $1980 \mathrm{~s}$, concentrated on management-type activities such as organization, supervision, and attainment of group performance goals (Burns, 1978). Transactional theories based successful leadership on a system of rewards and punishment (Bass, 1985), wherein employees were rewarded for performance, and reprimanded or punished when they missed the mark (Bass, 1990; Chakraborty \& Chakraborty, 2004). Transactional leadership techniques are effective during stable times but are less useful in times of turbulent change (Kirkbride, 2006).

Downton first introduced the term transformational leadership in 1979 to describe the connection, relationship, or influence between leaders and their direct reports (Bass, 1985). Transformational leaders incorporate inspiration, enthusiasm, and motivational support to encourage their teams to see the importance of the higher goal or the meaningful work being done and to rise up to meet these demands (Tucker\& Russell, 2004). Transformational leaders are aware of the performance of the team overall, but are also focused on encouraging each person to fulfill his or her full potential (Bass, 1985). According to Bass (1985), transformational leaders usually have high ethical and moral values. Therefore, transformational leadership goes beyond meeting the basic needs of the leader's direct reports (Kouzes\& Posner, 1987), taking the relationship between the leader and the followers to the next level (Burns, 1978, p.20). This results in a joint purpose or common goal, and therefore, transformational leaders create, change, and improve the culture within the organization, which ultimately heightens the performance of all participants - from the leader to the followers (Burns, 1978, p.20; Kouzes \& Posner, 1987).

Bass (1996) further suggested that transformational leadership could have an impact on overall organizational performance. According to the current literature, transformational leadership is strongly associated with positive job characteristics, including employee job satisfaction, organizational commitment, organizational effectiveness, and employee productivity (Dunham-Taylor, 2000; Duckett \& Macfarlane, 2003; Avolio \& Koh, 2004). This level of positive impact on organizational goals led to research into whether transformational leadership has a positive financial impact. Barrick, Day, Lord, and Alexander (1991) found 
that transformational leadership positively impacts an organization financially, estimating this impact at approximately "25 million dollars (after taxes) throughout an executive's average career span” (p. 19). Maister (2001) and Kotter and Heskett (1992) also found that leadership from individuals working within organizations has a positive impact on the organization's financial performance.

This positive return on investment for organizations with strong transformational leadership led Bass (1996) to propose that training on transformational leadership should be made accessible to all ranks or levels within an organization. As confirmed by Bass (1996), Kouzes and Posner (2002, p. 383), and Judge and Piccolo (2004), the core concepts of transformational leadership can be learned and applied by everyone. This study develops hypotheses based on an examination of previous research into transformational leadership and leadership effectiveness.

\subsection{Resilience to Change}

As the world is changes constantly, organizations and individuals alike are under pressure to keep up. Organizations require resilience in the current business environment (Luthans, Youssef, \& Avolio, 2006; Norman et al., 2005). Resilience to change develops as people grow in experience, learn skills of self-awareness, and increase their general knowledge of the world. Resilience to change is an attribute or capacity that involves action, thoughts, characteristics, and behaviors. A resilient individual taps into their resources, such as their family and friends, as a support system, and leverages their personal strengths. Personal development comes not through the experience of facing adversity, but rather the process of struggling, learning, and tenaciously moving forward through the challenge. The current research suggests a common denominator and defines resilience to change as a human capacity, strength, or ability (Conner, 2000).

While it would appear logical that transformational-type leaders would want to possess resiliency, at least as illustrated in this study, a comprehensive literature review reveals rather modest experimental research associating the concepts of leadership and resilience, especially on the frontlines of organizations, and in sales professionals specifically. According to Bass (1996), transformational leadership leads to positive organizational changes; it would seem that more resilient leaders may possess the ability to handle the routine failures, setbacks, and change common in business. Leaders invoking resilience to change, especially during turbulent times, may help encourage others toward greater effort and higher performance during challenging times.

\subsection{Transformational Leadership and Resilience to Change}

It is these concepts of transformational leadership and resilience to change that are the focus of this study, establishing the following research questions and their associated hypotheses:

1. What is the relationship between the dimensions of resilience and the transformational leadership behaviors demonstrated by sales professionals?

Hypothesis 1: Higher resilience scores for sales professionals are related to a higher 
aggregate transformational leadership behavior score.

2. Does the transformational leadership behavior of sales professionals differ relative to gender, age, level of education, years of experience in the current position, and salary level?

Hypothesis 2-1: There is a significant difference in the aggregate transformational leadership behavior score of male and female sales professionals.

Hypothesis 2-2: There is a significant relationship between the aggregate transformational leadership behavior score and the age of sales professionals.

Hypothesis 2-3: There is a significant relationship between the level of education and the aggregate transformational leadership behavior score of sales professionals.

Hypothesis 2-4: There is a significant relationship between the aggregate transformational leadership behavior score and the job tenure of sales professionals.

Hypothesis 2-5: There is a significant relationship between the aggregate transformational leadership behavior score and the salary level of sales professionals.

3. Which of the dimensions of resilience and key socio-demographic variables are most predictive of the transformational leadership behavior demonstrated by sales professionals?

Hypothesis 3: A change in the level of resilience along with a change in key socio-demographic variables can be used to predict a change in the respondents' aggregate transformational leadership behavior score.

\section{Method}

\subsection{Sample and Procedure}

The sample consisted of a previously recruited, computer-randomized group of approximately 2250 full- or part-time sales professionals who are employed and live in the United States, and represent a panel of research participants obtained from MarketTools, a market research firm with a recruited database of 2.4 million volunteer consumers. The participants were identified based on current employment in a sales profession as specified on their MarketTools profile, representing both genders over the age of 18 and both large and small industries. The profile of prospective panelists was crossed-validated with third party consumer financial institutions to confirm the panelists' identities and locations. Once the key attributes to ensure representation of the general population were identified, a list of prospective research participants was randomized multiple times per minute until the final panel was pulled. The respondents, totaling 356, belonged to a diverse set of industries located in the United States (M. Wilner, MarketTools, Personal Communication, January 9, 2009).

The research participants for this independent study included 197 frontline sales professionals (104 Managers), of which 55\% were male, and the modal response category for age was between 19 and 80 years. Roughly $85.3 \%$ of the sample indicated that they are Caucasian. The average industry experience for the research participants was 12.93 years (with a range of 45 years) across approximately 26 different industries, while the average tenure in their current 
employment was 6.86 years (with a range of 45 years). The education level was distributed as follows: $37 \%$ of the research respondents indicated that they possessed a high school diploma, $22 \%$ indicated that they possessed an associate and/or technical degree, and $30 \%$ possessed a 4-year college degree.

\subsection{Instruments}

The study used two pre-validated instruments: The Leadership Practices Inventory (LPI) and the Personal Resilience Questionnaire (PRQ), along with a socio-demographic questionnaire.

\subsubsection{The Leadership Practices Inventory (LPI)}

The LPI-Self Form was selected to assess transformational leadership because it has strong academic research supporting its sound psychometric properties. Kouzes and Posner (1987) developed the LPI based on transformational leadership theory. By triangulating qualitative and quantitative research methods, combined with in-depth interviews regarding individuals' best practice leadership experiences, Kouzes and Posner generated the five practices regularly exhibited by exemplary leaders: challenging the process, modeling the way, inspiring a shared vision, enabling others to act, and encouraging the heart. The LPI-Self Form is a 30 -item questionnaire measuring behaviors on a scale of 1 to 10 , with 1 representing never and 10 representing almost always, grouped under the five behaviors of exemplary leadership with each including six practices. The LPI questionnaire scores each practice separately with an average total ranging from six to sixty points for each of the five separate behaviors or sub-scales (Kouzes \& Posner, 2002, p. 88). A perfect score on each of the transformational leadership behaviors is sixty, for a total overall perfect score of 300 . Both the Self and the Observer LPT forms were developed and exposed to the same psychometric analyses used to determine reliability and to validate the initial LPI research instrument.

The LPI has good internal reliability, test-retest reliability, concurrent validity, and discriminate validity (Kouzes \& Posner 1995; Zagorsek, Stough \& Jaklic, 2004). A review of academic and organizational studies using the LPI suggests that the LPI is a well-documented, reliable, and validated framework compared to other leadership instruments (Cangelosi \& Whitt, 2005). Additionally, Kouzes and Posner (2002) have consistently evaluated the LPI survey every two years since its initial development in 1987. The LPI has been well researched and documented in the literature, and demonstrates strong consistency over time (Lewis, 1995, p. 557).Permission to use the LPI-Self questionnaire was obtained from Dr. Barry Posner.

Table 1 presents the reliability of the 36-item LPI-Selfform for this research study. Cronbach's alpha coefficients for the transformational leadership behaviors ranged from 0.756 to 0.868 , indicating strong internal reliability for all subscales. Overall, the Cronbach's alpha coefficient for the entire LPI survey was 0.955 . Consequently, there was sufficient evidence to support the internal consistency of the LPI and each of the individual practices or subscales for this study, indicating that all transformational leadership subscales and the total transformational leadership scores were appropriate for the various analyses outlined in this research. 
Table 1. Internal Consistency and Reliability for the LPI Questionnaire

\begin{tabular}{|l|l|l|l|l|}
\hline Scale(number of Items) & $N$ & $M$ & SD & $\begin{array}{l}\text { Cronbach's } \\
\text { Alpha }\end{array}$ \\
\hline Total LPI (36) & 197 & 7.313 & 2.073 & 0.955 \\
\hline Modeling the Way (6) & 197 & 7.573 & 1.989 & 0.768 \\
\hline Challenging the Process (6) & 197 & 6.735 & 2.173 & 0.830 \\
\hline Inspiring a Shared Vision (6) & 197 & 6.729 & 2.252 & 0.868 \\
\hline Enabling Others to Act (6) & 197 & 7.976 & 1.830 & 0.756 \\
\hline Encouraging the Heart (6) & 197 & 7.552 & 2.017 & 0.860 \\
\hline
\end{tabular}

3.2.2 The Personal Resilience Questionnaire (PRQ)

The PRQ was used to assess personal resilience. Daryl Conner and his associates at ODR, Inc. (now Conner Partners) developed the instrument in 1990 (PRQ, 1993) as they worked to define the elements that accompanied a resilient nature (Conner, 1993). The PRQ consists of 70 questions that align with the seven resilience dimensions, and each is simple enough for most individuals assessed within an organizational environment to read and understand the survey questions/statements as written (Conner, 1993). The PRQ uses a 6-point Likert scale with items ranging from Strongly Disagree to Strongly Agree, though without the option of a neutral response (e.g., don't know, unsure, undecided) in a decisive effort to compel research participants to make a choice on every survey item (Judd, Smith \& Kidder, 1991). Additionally, approximately $50 \%$ of the survey items are reverse scored to manage and reduce simple response bias (Conner, 1993). Permission to use the PRQ questionnaire was granted by Dr. Linda Hoopes through a non-disclosure agreement, though the PRQ coding scheme is held confidential at Dr. Hoopes' request. It is available only if additional backup documentation is needed to highlight how the data was derived.

The PRQ was selected for this research study because, like the LPI, it is a reliable and well-validated comparative instrument that has been used and documented in other research projects. Additionally, the PRQ has been tested with more than 50,000 participants, and most of the seven subscales are moderately to highly correlated. Measurements of reliability, internal consistency, and stability are $0.65,0.83$, and 0.85 , respectively, as measured by Cronbach $\alpha$ for the entire measure. The PRQ instrument has also been tested and proven to demonstrate convergent, discriminant, and predictive validity (Conner Partners, 2004).

Table 2 provides the internal consistency scores for the PRQas confirmed for this study. While two of the dimensions, Flexible-Thoughts and Proactive, possessed somewhat lower alpha 


\section{Macrothink

levels with the overall reliability of the 70-item PRQ being 0.945 , and Cronbach's alpha coefficients for the resilience dimensions ranging from 0.678 to 0.846 . Once again, there was sufficient evidence to support the internal consistency of the PRQ and, therefore, it was appropriate to include all dimensions of resilience in the analyses.

Table 2. Internal Consistency and Reliability for the Personal Resilience Questionnaire

\begin{tabular}{|l|l|l|l|l|}
\hline Scale(number of items) & $N$ & $M$ & $S D$ & $\begin{array}{l}\text { Cronbach's } \\
\text { Alpha }\end{array}$ \\
\hline Total PRQ (70) & 197 & 4.093 & 1.319 & 0.945 \\
\hline Positive-the world (10) & 197 & 4.280 & 1.302 & 0.846 \\
\hline Positive-Yourself (10) & 197 & 4.441 & 1.273 & 0.834 \\
\hline Focused (10) & 197 & 4.224 & 1.343 & 0.842 \\
\hline Flexible-Thoughts (10) & 197 & 3.704 & 1.273 & 0.702 \\
\hline Flexible-Social (10) & 197 & 4.166 & 1.308 & 0.735 \\
\hline Organized (10) & 197 & 4.049 & 1.386 & 0.716 \\
\hline Proactive (10) & 197 & 3.788 & 1.342 & 0.678 \\
\hline
\end{tabular}

\subsubsection{Descriptive Statistics}

LPI.Since this study combined questions from two pre-validated surveys, Table 3 shows the number of questions that comprised each leadership sub-scale and the associated means and standard deviations. 
Table 3. Means and Standard Deviations for Transformational Leadership Behaviors (Outliers Removed)

\begin{tabular}{|l|l|l|}
\hline $\begin{array}{l}\text { Kouzes' and Posner's Leadership } \\
\text { Practices Subscales }\end{array}$ & $\begin{array}{l}\text { Questions comprising the } \\
\text { subscales in this Survey }\end{array}$ & Mean (SD) \\
\hline Aggregate Leadership Score & Sum of all Questions & $219.39(40.73)$ \\
\hline Modeling the Way & Sum of 2, 7, 12, 17, 22, 27 & $45.44(8.12)$ \\
\hline Challenging the Process & Sum of 4, 9, 14, 19, 24, 29 & $40.41(9.58)$ \\
\hline Inspiring a Shared Vision & Sum of 3, 8, 13, 18, 23, 28 & $40.37(10.48)$ \\
\hline Enabling Others to Act & Sum of 5, 10,15, 20, 25, 30 & $47.86(7.37)$ \\
\hline Encouraging the Heart & Sum of 6, 11, 16, 21, 26, 31 & $45.31(9.25)$ \\
\hline
\end{tabular}

Table 4 depicts the minimum and maximum ranges, the means, and the standard deviations of the research participants' responses to the questions on the LPI. For the LPI, responses ranged from 16.00 to 60.00 for Modeling the Way, 11.00 to 60.00 for Challenging the Process, 7.00 to 59.00 for Inspiring a Shared Vision, 15.00 to 60.00 for Enabling Others to Act, and 15.00 to 60.00 for Encouraging the Heart.

Table 4. Descriptive Statistics of Survey Responses for the Dependent Variable, Transformational Leadership: LPI $(\mathrm{N}=197)$

\begin{tabular}{|l|l|l|l|}
\hline LPI & Minimum-Maximum & $M$ & $S D$ \\
\hline Modeling the Way & $(16.00,60.00)$ & 45.4365 & 8.11727 \\
\hline Challenging the Process & $(11.00,60.00)$ & 40.4112 & 9.58200 \\
\hline Inspiring a Shared Vision & $(7.00,59.00)$ & 40.3723 & 10.48245 \\
\hline Enabling Others to Act & $(15.00,60.00)$ & 47.8589 & 7.36834 \\
\hline Encouraging the Heart & $(15.00,60.00)$ & 45.3147 & 9.25337 \\
\hline
\end{tabular}

Table 5 provides a comparison of the data from this assessment of the transformational leadership behaviors of frontline sales professionals with normative data provided by Kouzesand Posner (2008), which shows that the data trends in a similar fashion as the published normative data. 
Table 5. Study data compared with Normative Data Provided by Kouzes and Posner Self-Reported Form

\begin{tabular}{|l|l|l|}
\hline $\begin{array}{l}\text { Five Exemplary Leadership } \\
\text { Behaviors }\end{array}$ & $\begin{array}{l}\text { Kouzes\&Posner'sNorms- } \\
\text { Self-reported Questionnaire } \\
(N=74,294) \\
M(S D)\end{array}$ & $\begin{array}{l}\text { Frontline Sales Professionals } \\
\text { Questionnaire } \\
(N=197) \\
\text { Self-reported }\end{array}$ \\
\hline Modeling the Way & $45.15(6.92)(2)$ & $45.44(8.11)(2)$ \\
\hline Challenging the Process & $43.02(7.73)(4)$ & $40.41(9.58)(4)$ \\
\hline Inspiring a Shared Vision & $41.11(9.44)(5)$ & $40.37(10.48)(5)$ \\
\hline Enabling Others to Act & $49.43(5.61)(1)$ & $47.86(7.37)(1)$ \\
\hline Encouraging the Heart & $44.23(8.58)(3)$ & $45.31(9.25)(3)$ \\
\hline
\end{tabular}

$P R Q$. In addition, research participants ranked each item on the PRQ questionnaire using a 6-point Likert Scale that ranged from 1-Strongly Disagree to 6-Strongly Agree. This number was divided by the number of valid responses, and then multiplied by 20 , creating a scale of 1 to 100 for each individual question. All of the resilience dimensions were calculated in the same manner. While individuals' responses containing 5 or less completed answers out of the 10 questions could be less likely to be accurate due to missing data and could skew the results, this was not an issue so no question or response had to be eliminated for this reason alone. 


\section{Macrothink}

Table 6. Means for Dimensions of Resilience for Frontline Sales Professionals

\begin{tabular}{|l|l|l|}
\hline & & $\begin{array}{l}\text { Sales Professionals } \\
(N=197)\end{array}$ \\
\hline Conner's PRQ & $\begin{array}{l}\text { Questions on Survey for each Dimension } \\
\text { of Resilience }\end{array}$ & $\begin{array}{l}\text { Means for each Subscale } \\
\text { (ranked by behavior } \\
\text { reported to } \\
\text { demonstrated } \\
\text { frequently) }\end{array}$ \\
\hline Positive-the World & $3,39,42,44,48,52,56,75,88,99$ & $66.21(2)$ \\
\hline Positive-Yourself & $33,47,49,54,70,78,84,86,90,93$ & $70.25(1)$ \\
\hline Focused & $35,58,65,68,74,76,79,83,85,101$ & $65.26(3)$ \\
\hline Flexible-Thoughts & $32,34,38,53,62,67,71,81,97,100$ & $54.81(7)$ \\
\hline Flexible-Social & $37,40,43,50,57,59,60,63,69,82$ & $63.68(4)$ \\
\hline Organized & $51,61,66,72,73,89,91,94,96,98$ & $61.97(5)$ \\
\hline Proactive & $41,45,46,55,64,77,80,87,92,95$ & $56.79(6)$ \\
\hline
\end{tabular}

\subsection{Analysis and Results}

This study adopted several analytical methods to provide descriptive data on the research participants, test the hypothesized impact of the dimensions of resilience and key demographics on the transformational leadership behaviors of sales professionals, and ensure the reliability and validity of each of the measures incorporated in the study.

An analysis of Pearson's correlation between the individual resilience scores for each of the dimensions and the overall transformational leadership was conducted to determine the answer for research question 1. If Pearson's Correlation was non-significant, there would be no correlation between the dependent variable, transformational leadership behaviors, and the independent variables, the dimensions of resilience. There would then be no reason to test the hypothesis for research question 3 . Table 7 shows the analytical results and that all dimensions of resilience have statistically significant correlations with the overall transformational leadership score $(p<0.01)$. 
Table 7. Pearson Correlation between Dimensions of Resilience Scores and Overall Transformational Leadership Score $(\mathrm{N}=197)$

\begin{tabular}{|l|l|l|}
\hline $\begin{array}{l}\text { Dimensions of Resilience and Overall } \\
\text { Transformational Leadership }\end{array}$ & $\mathrm{R}$ & R Squared \\
\hline $\begin{array}{l}\text { Positive-the World and Overall } \\
\text { Transformational Leadership }\end{array}$ & $.386^{* *}$ & .1490 \\
\hline $\begin{array}{l}\text { Positive-Yourself and Overall } \\
\text { Transformational Leadership }\end{array}$ & $.382^{* *}$ & .1459 \\
\hline $\begin{array}{l}\text { Focused and Overall Transformational } \\
\text { Leadership }\end{array}$ & $.407^{* *}$ & .1656 \\
\hline $\begin{array}{l}\text { Flexible-Thoughts and Overall } \\
\text { Transformational Leadership }\end{array}$ & $.284^{* *}$ & .0807 \\
\hline $\begin{array}{l}\text { Flexible-Social and } \\
\text { Transformational Leadership }\end{array}$ & $.334^{* *}$ & .1116 \\
\hline $\begin{array}{l}\text { Organized and Overall Transformational } \\
\text { Leadership }\end{array}$ & $.342^{* *}$ & $.370^{* *}$ \\
\hline $\begin{array}{l}\text { Proactive and Overall Transformational } \\
\text { Leadership }\end{array}$ & .1369 \\
\hline
\end{tabular}

Note. Significance levels: $* * * 0.001, * * 0.01, * 0.05$, preset level of significance $=0.05$.

A $t$ test of equality of means was used to assess whether transformational leadership varied by gender by determining if there was a significant difference between the group means for the aggregate (total) transformational leadership behaviors score of frontline sales professionals by gender. Table 8 shows the results of the $t$ test analysis. The mean score for total transformational leadership score was higher for men (220.0491) than for women (218.5818), however, the difference was not statistically significant. Additionally, a statistically significant difference in the transformational leadership behaviors demonstrated by gender was not found with any of the subscales of transformational leadership behaviors. Hypothesis 2-1 was not supported since there was no significant difference ( $p$-value was greater than 0.05 ).

This data agrees with the normative data provided by Kouzes and Posner (2009).Generally, transformational leadership behaviors are not significantly different for males and females on the LPI Self-form, as both genders report engaging in all associated behaviors with about the same frequency. Other researchers have reported similar results in regards to gender and leadership practices within a variety of sample populations. 
Table 8. $t$ Test for Differences in Transformational Leadership Behaviors by Gender

\begin{tabular}{|c|c|c|c|c|c|c|c|c|}
\hline & \multicolumn{2}{|l|}{$N$} & \multicolumn{2}{|l|}{$M$} & \multicolumn{2}{|l|}{$S D$} & \multirow[b]{2}{*}{$t$} & \multirow[b]{2}{*}{$P$} \\
\hline & Male & Female & Male & Female & Male & Female & & \\
\hline Modeling the Way & 109 & 88 & 45.49 & 45.38 & 8.38 & 7.83 & 0.095 & .924 \\
\hline $\begin{array}{l}\text { Challenge the } \\
\text { Process }\end{array}$ & 109 & 88 & 40.36 & 40.48 & 9.71 & 9.47 & -0.087 & .931 \\
\hline $\begin{array}{l}\text { Inspire a Shared } \\
\text { Vision }\end{array}$ & 109 & 88 & 40.73 & 39.93 & 10.53 & 10.47 & 0.529 & .597 \\
\hline $\begin{array}{l}\text { Enable Others to } \\
\text { Act }\end{array}$ & 109 & 88 & 47.85 & $47.8 \underline{7}$ & 7.51 & 7.23 & -0.012 & .990 \\
\hline $\begin{array}{l}\text { Encourage the } \\
\text { Heart }\end{array}$ & 109 & 88 & 45.62 & 44.93 & 9.64 & 8.80 & 0.521 & .603 \\
\hline $\begin{array}{l}\text { Total } \\
\text { Transformational } \\
\text { Leadership }\end{array}$ & 109 & 88 & 220.05 & 218.58 & 41.50 & 39.98 & 0.251 & .802 \\
\hline
\end{tabular}

Research Question 2 further addressed the association between the socio-demographic variables of age, level of education, job tenure, and salary level and total transformational leadership behaviors demonstrated by frontline sales professionals. The overall relationship between these selected variables with the dependent variable, total transformational leadership behaviors, was initially tested using Pearson's Product-Moment Correlation and then Kendall Tau-b statistics, with the results shown in Table 9. Pearson's Product-Moment Correlation is a measure of the strength of the linear dependence between two variables (independent versus dependent variables; Gall, Gall \& Borg, 2005). Kendall Tau is a nonparametric correlation coefficient based on a data ranking when all of the data are ordinal (Gall, Gall \& Borg, 2005).

These measures did not identify any of the demographic characteristics with a significant relationship at the 0.05 level or better $(p<0.01)$ to the dependent variable. There was a significant Kendall tau-b correlation of 0.552 between tenure and age. Additionally, income was significantly correlated with three demographic variables: age, education, and tenure (age, Kendall tau- $\mathrm{b}=0.295, \mathrm{p}<0.001$; education, Kendall tau- $\mathrm{b}=0.143, p=0.029$; tenure, Kendall tau-b $=0.279, p<0.001)$. 
Table 9. Kendall Tau Correlations for Demographics and Total Transformational Leadership

\begin{tabular}{|c|c|c|c|c|c|c|}
\hline $\begin{array}{l}\text { Kendall } \\
\text { tau-b }\end{array}$ & & Leadership & Age & Education & Tenure & Income \\
\hline \multirow[t]{3}{*}{ Leadership } & $\begin{array}{l}\text { Correlation } \\
\text { Coefficient }\end{array}$ & 1.000 & -.016 & .073 & -.006 & .011 \\
\hline & Sig. (2-tailed) & & .745 & .197 & .899 & .839 \\
\hline & $\mathrm{N}$ & 197 & 194 & 184 & 197 & 194 \\
\hline \multirow[t]{3}{*}{ Age } & $\begin{array}{l}\text { Correlation } \\
\text { Coefficient }\end{array}$ & -.016 & 1.000 & .109 & $.552 * *$ & $.295 * *$ \\
\hline & Sig. (2-tailed) & .745 & . & .058 & .000 & .000 \\
\hline & $\mathrm{N}$ & 194 & 194 & 181 & 194 & 192 \\
\hline \multirow[t]{3}{*}{ Education } & $\begin{array}{l}\text { Correlation } \\
\text { Coefficient }\end{array}$ & .073 & .109 & 1.000 & .044 & $.143^{*}$ \\
\hline & Sig. (2-tailed) & .197 & .058 & . & .462 & .029 \\
\hline & $\mathrm{N}$ & 184 & 181 & 184 & 184 & 181 \\
\hline \multirow[t]{3}{*}{ Tenure } & $\begin{array}{l}\text { Correlation } \\
\text { Coefficient }\end{array}$ & -.006 & $.552 * *$ & .044 & 1.000 & $.279 * *$ \\
\hline & Sig. (2-tailed) & .899 & .000 & .462 & . & .000 \\
\hline & $\mathrm{N}$ & 197 & 194 & 184 & 197 & 194 \\
\hline \multirow[t]{3}{*}{ Income } & $\begin{array}{l}\text { Correlation } \\
\text { Coefficient }\end{array}$ & -.011 & $.295 * *$ & $.143^{*}$ & $.279 * *$ & 1.000 \\
\hline & Sig. (2-tailed) & .839 & .000 & .029 & .000 & . \\
\hline & $\mathrm{N}$ & 194 & 192 & 181 & 194 & 194 \\
\hline
\end{tabular}

A one-way analysis of variance (ANOVA) was calculated to test whether the transformational leadership behavior demonstrated by frontline sales professionals varied by age. The 
independent demographic variable, age, was operationalized into 10 categories as listed in Table 10. If there were significant differences, a Scheffe post hoc analysis was used to clarify which age groups were significantly different in the level of total transformational leadership if the mean differences were statistically significant. Table 10 suggests that there was no significant difference between age categories with regard to transformational leadership, so no Scheffe tests were needed. Accordingly, hypothesis 2-2 was not supported.

Kouzes and Posner's normative data (2009) used different age categories than those in this study, and demonstrated that as research respondents' age increased, so did the frequency with which they demonstrated transformational leadership behaviors.

Table 10. One-way ANOVA on Total Transformational Leadership by Age

\begin{tabular}{|c|c|c|c|c|c|}
\hline Years & $N$ & \multicolumn{2}{|l|}{$M$} & \multicolumn{2}{|c|}{$S D$} \\
\hline$<21$ & 10 & \multicolumn{2}{|c|}{217.6200} & \multicolumn{2}{|c|}{29.74745} \\
\hline $21-25$ & 24 & \multicolumn{2}{|c|}{224.0417} & \multicolumn{2}{|c|}{38.30482} \\
\hline $26-30$ & 26 & \multicolumn{2}{|c|}{217.7692} & \multicolumn{2}{|c|}{46.23186} \\
\hline $31-35$ & 23 & \multicolumn{2}{|c|}{209.0587} & \multicolumn{2}{|c|}{49.84496} \\
\hline $36-40$ & 17 & \multicolumn{2}{|c|}{229.4706} & \multicolumn{2}{|c|}{41.09914} \\
\hline $41-45$ & 20 & \multicolumn{2}{|c|}{232.7000} & \multicolumn{2}{|c|}{29.99667} \\
\hline $46-50$ & 13 & \multicolumn{2}{|c|}{195.0769} & \multicolumn{2}{|c|}{46.19066} \\
\hline $51-55$ & 21 & \multicolumn{2}{|c|}{231.3333} & \multicolumn{2}{|c|}{43.18372} \\
\hline $56-60$ & 13 & \multicolumn{2}{|c|}{216.3846} & \multicolumn{2}{|c|}{21.08530} \\
\hline$>60$ & 27 & \multicolumn{2}{|c|}{215.0370} & \multicolumn{2}{|c|}{40.23822} \\
\hline $\begin{array}{l}\text { Transformational } \\
\text { Leadership } \\
\text { Behavior }\end{array}$ & $\mathrm{SS}$ & Df & MS & $\mathrm{F}$ & $P$ \\
\hline
\end{tabular}

An ANOVA analysis was performed to determine if any significant differences exists between the transformational leadership behaviors of sales professionals varied based on educational attainment. The independent demographic variable, educational level was operationalized into five categories as depicted in Table 11, which also shows the results of the ANOVA and 


\section{Ml Macrothink}

Scheffe analyses. Once again, however, there were no significant results since the $p$-value for the ANOVA test was 0.072 and greater than .05, so no Scheffe tests were conducted. Consequently, the results in Table 11 provide insufficient evidence to support Hypothesis 2-3.In general, the LPI scores have been found to be unrelated with demographic characteristics (e.g., marital status, years of experience, and education level).

Table 11. One-way ANOVA on Total Transformational Leadership by Education

\begin{tabular}{|c|c|c|c|c|c|}
\hline Education Level & $N$ & \multicolumn{2}{|l|}{$M$} & \multicolumn{2}{|l|}{$S D$} \\
\hline High School Degree & 72 & \multicolumn{2}{|c|}{218.6389} & \multicolumn{2}{|c|}{37.67739} \\
\hline $\begin{array}{l}\text { Associate's/Technical } \\
\text { Degree }\end{array}$ & 44 & \multicolumn{2}{|c|}{216.8864} & \multicolumn{2}{|c|}{41.42587} \\
\hline $\begin{array}{l}\text { 4-year } \quad \text { College } \\
\text { Degree }\end{array}$ & 59 & \multicolumn{2}{|c|}{224.1559} & \multicolumn{2}{|c|}{39.87498} \\
\hline Master's Degree & 6 & \multicolumn{2}{|c|}{257.2250} & \multicolumn{2}{|c|}{13.89690} \\
\hline $13-15$ & 3 & \multicolumn{2}{|c|}{183.0000} & \multicolumn{2}{|c|}{91.92932} \\
\hline $\begin{array}{l}\text { Transformational } \\
\text { Leadership Behavior }\end{array}$ & SS & $\mathrm{Df}$ & MS & $\mathrm{F}$ & $P$ \\
\hline Between Groups & 13918.573 & 4 & 3479.643 & 2.188 & .072 \\
\hline Within Groups & 284671.467 & 179 & 1590.343 & & \\
\hline Total & 298590.040 & 183 & & & \\
\hline
\end{tabular}

An ANOVA analysis was performed to determine if a significant difference exists between the transformational leadership behaviors of frontline sales professionals based on job tenure in their current position. The independent demographic variable, job tenure, was operationalized into 11 categories as listed in Table 12. The average tenure was 6.86 years, with a range of 45 years, which seems to be relatively significant in the current economy. However, Table 12 indicates that no significant differences existed for sales professionals with varying years of experience $(p$-value $=0.087$ ); therefore, no Scheffe analysis was conducted. Hence, Hypothesis 2-4 is not supported. 
Table 12. One-way ANOVA on Total Transformational Leadership by Job Tenure

\begin{tabular}{|c|c|c|c|c|c|}
\hline Years & $N$ & \multicolumn{2}{|l|}{$M$} & \multicolumn{2}{|l|}{$S D$} \\
\hline $1-3$ & 37 & \multicolumn{2}{|c|}{223.8703} & \multicolumn{2}{|c|}{28.72360} \\
\hline $4-6$ & 27 & \multicolumn{2}{|c|}{203.6667} & \multicolumn{2}{|c|}{54.25935} \\
\hline $7-9$ & 28 & \multicolumn{2}{|c|}{216.0000} & \multicolumn{2}{|c|}{46.07562} \\
\hline $10-12$ & 29 & \multicolumn{2}{|c|}{228.8741} & \multicolumn{2}{|c|}{34.10910} \\
\hline $13-15$ & 12 & \multicolumn{2}{|c|}{237.8333} & \multicolumn{2}{|c|}{54.29353} \\
\hline $16-18$ & 11 & \multicolumn{2}{|c|}{240.7273} & \multicolumn{2}{|c|}{26.16521} \\
\hline $19-21$ & 15 & \multicolumn{2}{|c|}{216.4000} & \multicolumn{2}{|c|}{37.57621} \\
\hline $22-24$ & 9 & \multicolumn{2}{|c|}{191.4444} & \multicolumn{2}{|c|}{28.88819} \\
\hline $25-27$ & 9 & \multicolumn{2}{|c|}{215.2222} & \multicolumn{2}{|c|}{44.35588} \\
\hline $28-30$ & 6 & \multicolumn{2}{|c|}{221.5000} & \multicolumn{2}{|c|}{38.44346} \\
\hline$>30$ & 14 & \multicolumn{2}{|c|}{215.4286} & \multicolumn{2}{|c|}{31.84509} \\
\hline $\begin{array}{l}\text { Transformational } \\
\text { Leadership } \\
\text { Behavior }\end{array}$ & $\mathrm{SS}$ & Df & MS & $\mathrm{F}$ & $P$ \\
\hline Between Groups & 27003.399 & 10 & 2700.340 & 1.684 & .087 \\
\hline Within Groups & 298171.835 & 186 & 1603.074 & & \\
\hline Total & 325175.235 & 196 & & & \\
\hline
\end{tabular}

An ANOVA analysis was conducted to evaluate if any significant differences exist between total transformational leadership behaviors by salary level. The independent socio-demographic variable, salary level, was operationalized into eight categories as depicted Table 13. Table 13 suggests there was no significant difference in transformational leadership behaviors demonstrated by frontline sales professionals with varying income levels ( $p$-value $=0.777)$, therefore, no Scheffe post hoc analyses were required, and Hypothesis 2-5 was not supported. 


\section{Macrothink}

Table 13. One-way ANOVA on Transformational Leadership by Salary Level

\begin{tabular}{|c|c|c|c|c|c|}
\hline Salary Level & $N$ & \multicolumn{2}{|l|}{$M$} & \multicolumn{2}{|l|}{$S D$} \\
\hline$<\$ 40,000$ & 125 & \multicolumn{2}{|c|}{220.4256} & \multicolumn{2}{|c|}{41.43312} \\
\hline$\$ 40,000-50,000$ & 31 & \multicolumn{2}{|c|}{214.9032} & \multicolumn{2}{|c|}{35.45923} \\
\hline$\$ 51,000-60,000$ & 10 & \multicolumn{2}{|c|}{215.7000} & \multicolumn{2}{|c|}{39.76053} \\
\hline$\$ 61,000-70,000$ & 6 & \multicolumn{2}{|c|}{206.5000} & \multicolumn{2}{|c|}{44.67997} \\
\hline$\$ 71,000-80,000$ & 7 & \multicolumn{2}{|c|}{229.8571} & \multicolumn{2}{|c|}{43.80802} \\
\hline$\$ 81,000-90,000$ & 5 & \multicolumn{2}{|c|}{219.8000} & \multicolumn{2}{|c|}{18.43095} \\
\hline$\$ 91,000-100,000$ & 8 & \multicolumn{2}{|c|}{211.8750} & \multicolumn{2}{|c|}{65.64937} \\
\hline$>\$ 100,000$ & 2 & \multicolumn{2}{|c|}{262.6750} & \multicolumn{2}{|c|}{1.87383} \\
\hline $\begin{array}{l}\text { Transformational } \\
\text { Leadership } \\
\text { Behavior }\end{array}$ & $\mathrm{SS}$ & Df & MS & $\mathrm{F}$ & $P$ \\
\hline Between Groups & 6855.430 & 7 & 979.347 & .573 & .777 \\
\hline Within Groups & 317847.551 & 186 & 1708.858 & & \\
\hline Total & 324702.981 & 196 & & & \\
\hline
\end{tabular}

The analysis indicates that the socio-demographic variables accounted for very little of the variance or impact on the transformational leadership behaviors demonstrated by frontline sales professionals. In research conducted previously by Kouzes and Posner (2008) and others, 10 separate socio-demographic variables were evaluated for their ability to predict transformational leadership, and these included: gender, age, level of education, ethnicity, function, hierarchical level, industry, job tenure with the company, organizational size, and country location (Kouzes\& Posner, 2008). The previous research into the impact of socio-demographic variables on the total transformational leadership accounted for no more than 0.02 percent of the variance in demonstrations of this behavior (Kouzes \& Posner, 2008). This means that little to no explained variance in transformational leadership behaviors are learned by knowing more of the demographic features about the individuals responding to the LPI survey questions. Consequently, this study corroborates the existing literature on the 
impact assessed by a regression analysis of key demographics on the transformational leadership behaviors of various research respondents/participants. Therefore, standard socio-demographic characteristics did not explain the frequency with which transformational leaders invoked the five transformational leadership behaviors.

Based on the data provided in research question 1, several dimensions of resilience are strongly correlated with transformational leadership behaviors and that the socio-demographic variables from research question 2 do not explain the transformational leadership behaviors. Hypothesis 3 assesses which of the dimensions of resilience and socio-demographic variables are most predictive of the transformational leadership behaviors of frontline sales professionals.

To test the hypothesis associated with research question 3, a backward elimination multiple regression analysis was used to examine the impact of resilience and key demographics on the transformational leadership behaviors. In order to establish the validity of including a regression methodology in this study, the Pearson Product-Moment correlation among the independent and dependent variables was calculated, as suggested by Polit and Hungler (1987; See Table 9, Research Question 1). The statistically significant correlations substantiate the validity of the measures and, therefore, provide support for the use of regression techniques in this study. Of interest, is whether key demographics and the dimensions of resilience predict a sales professionals' likelihood of demonstrating transformational leadership behaviors. SPSS REGRESSION was used to perform the analysis, and SPSS EXPLORE was used to evaluate the assumptions. As stated by Cohen and Cohen (1983) and Hair (1995), incorporating backward elimination permitted an analysis allowing for a calculation of a regression equation with all independent variables (gender, age, level of education, job tenure, salary level, positive (the World), positive (Yourself), focused, flexible (Thoughts), flexible (Social), organized, and proactive), and then go back and delete the independent variables that did not contribute significantly to the equation. Using backward elimination also allowed for a determination of whether resilience adds any significant explanatory power to the model after controlling for the respondents' demographics.

\section{Results and Discussion}

This study demonstrated that there was a moderate but significant correlation between resilience to change and the transformational leadership behaviors of frontline sales professionals. No significant differences were found among the socio-demographic variables and the demonstrated transformational leadership behaviors or the dimensions of resilience. The results of the regression analysis demonstrated a significant relationship between the dimensions of resilience and transformational leadership behaviors, although the degree of correlation has a low to moderate impact $(22.7 \%)$.

\subsection{Key Findings}

In this study, frontline sales professionals demonstrated transformational leadership behaviors similar to the leadership behaviors found in other professional areas including general business, banking, nursing, and education (Kouzes\& Posner, 2014). Transformational leadership is 
important in academic and organization environments.It makes sense that transformational leadership behaviors are emphasized at all levels of the organization, even down to the frontlines of sales organizations, thus further confirming Bass and Burn's theories. If transformational leadership can be learned, then transformational leadership development and training should be implemented at all levels within an organization and not reserved only for the middle management and above.

Resilience to change allows individuals to make positive adaptations as change occurs and therefore warrants additional academic and organizational research given the pace of change of the Twenty-first Century. It is correlated with and predicts a positive low to moderate portion of the transformational leadership behaviors demonstrated by frontline sales professionals. Since resilience to change, like transformational leadership, can be learned, then resilience to change should also be part of corporate training programs if organizations want to create a competitive advantage within their respective organizations related to managing change in turbulent times.

As mentioned previously, the socio-demographic variables (gender, age, level of education, job tenure, and salary level) accounted for very little of the variance in the impact of transformational leadership behaviors demonstrated by frontline sales professionals which is in line with existing literature on the topic (Kouzes\& Posner, 2003).

\section{Limitations and Conclusions}

Although the sales professionals' response rate was powered appropriately to allow for all of the analyses in this study, some sales professionals may not have completed the surveys for varied reasons. Unfortunately, there is no approach available to evaluate or determine if there were any possible differences in the attitude, beliefs, or behaviors of those participants who elected not to or failed to participate versus those who did.

Finally, although 360-degree evaluations are believed to yield the most comprehensive results, this is often not practical in a research context (Van Hooft, Van der Flier, and Minne, 2006).Therefore, this study relied on self-reported responses. The self-report methodology is subject to biases that may result from the research participants' capacity to recall or remember events and/or routine characteristics as they occur. Additionally, under- or over-reporting is an ever-present bias, and participants may often desire to provide socially appropriate answers (Spector, 1994). Consequently, the data obtained from this exploratory independent study should be interpreted with a level of caution keeping these biases in mind. Nevertheless, given the response rate of $15.8 \%$, the research sample was of large enough size to evaluate all of the research questions outlined in this study.

Overall, this study found resilience to change is a positive, low to moderate predictor of transformational leadership behavior, explaining approximately $23 \%$ of the variance in the transformational leadership behaviors demonstrated by the frontline sales professionals in this study. The importance of transformational leadership and resilience to change throughout an organization cannot be emphasized enough and could encourage more effective acceptance of change as it occurs. Organizations need to stress resilience to change to enhance positive 
transformational leadership behaviors. However, there may be other contributing characteristics besides resilience that explains the transformational leadership behaviors of frontline sales professionals. Continued research should focus on understanding the transformational nature of leadership, a behavioral variable, and its relationship with the learned attitudinal variable, resilience to change.

\section{References}

Avolio, B. J., Zhu, W., \& Koh, W. (2004). Transformational leadership and organizational commitment: Mediating role of psychological empowerment and moderating role of structure distance. Journal of Organizational Behavior, 25(8), 951-968. http://dx.doi.org/10.1002/job.283

Barrick, M. R., Day, D. V., Lord, R. G., \& Alexander, R. A. (1991). Assessing the utility of executive leadership.Leadership Quarterly, 2(1), 9-22.

Bass, B. M. (1985). Leadership and performance beyond expectations.New York: FreePress.

Bass, B. (1990). From transactional to transformational leadership: Learning to share the vision. Organizational Dynamics, 18(1), 19-31.

Bass, B. M. (1996). A new paradigm of leadership: An inquiry into transformationalleadership. Alexandria, VA: U.S. Army Research Institute for the Behavioral and Social Sciences.

Becker, B., \& Gerhart, B. (1996). The impact of human resource management on organizational performance progress and prospects.Academy of Management Journal, 39(4), 779-801.

Bennis, W. (2007). The challenges of leadership in the modern world: introduction to the special issue. American Psychologist, 62(1), 2-5.http://dx.doi.org/10.1037/0003-066X.62.1.2

Burns, J. M. (1978). Leadership. New York: Harper and Row.

Cangelosi, P.R. \&Whitt, K.J. (2005).Accelerated Nursing Programs what do we know?.Nursing Education Perspectives, 26(2), 113-116.

Chakraborty, S., \& Chakraborty, D. (2004). The transformed leader and spiritual psychology: A few insights. Journal of Organizational Change Management, 17(2), 194-210. http://dx.doi.org/10.1108/09534810410530610

Chaharbaghi, K., Adcroft, A., \& Willis, R. (2005). Organizations, transformability, and the $\begin{array}{llll}\text { dynamics of } & \text { strategy.Management }\end{array}$ 6-12.http://dx.doi.org/10.1108/00251740510572443

Cohen, J., \& Cohen, P. (1983).Applied multiple regression/correlation analysis for the behavioral science. Hillsdale, NJ: Erlbaum.

Conner, D. R. (1993).Managing at the speed of change: How resilient managers succeedand prosper where others fail.New York: Villard Books.

Conner, D. R. (2000).Nimble organizations.Executive Excellence, 17(2), 18-19. 
Duckett, H., \& Macfarlane, E. (2003).Emotional intelligence and transformationalleadership in retailing.Leadership \& Organization Development Journal, 24(6), 309-317.http://dx.doi.org/10.1108/01437730310494284

Dunham-Taylor, J. (2000). Nurse executive transformational leadership found inparticipative organizations. The Journal of Nursing Administration, 30(5), 241-250.http://dx.doi.org/10.1097/00005110-200005000-00005

Gall, J. P., Gall, M. D., \& Borg, W. R. (2005). Applying educational research: A practical guide(5th ed.).Boston: Pearson Education.

Hair, J. (1995). Multivariate data analysis (4 ${ }^{\text {th }}$ ed.). Englewood Cliffs, NJ: Prentice-Hall.

Harland, L., Harrison, W., Jones, J. R., \& Reiter-Palmon, R. (2005). Leadership behaviorsand subordinate resilience.Journal of Leadership \& Organizational Studies, 11(2), 2-14.http://dx.doi.org/10.1177/107179190501100202

Judd, C., Smith, E., \& Kidder, L. (1991). Research methods in social relations.Orlando, Fl: Holt, Rinehart, and Winston.

Judge, T. A., \& Piccolo, R. F. (2004).Transformational and transactional leadership: a meta-analytic test of their relative validity. Journal of Applied Psychology, 89(5), 755-768.http://dx.doi.org/10.1037/0021-9010.89.5.755

Kirkbride, P. (2006). Developing transformational leaders: The full range leadershipmodel in action.Industrial and Commercial Training, 38(1), 23-32.http://dx.doi.org/10.1108/00197850610646016

Kotter, J. P., \& Heskett, J. I. (1992). Corporate cultures and performance.NewYork, NY: The Free Press.

Kouzes, J. M., \& Posner, B. Z. (1987). The leadership challenge: How to get extraordinary things done in organizations. San Francisco, CA: Jossey-Bass.

Kouzes, J. M., \& Posner, B. Z. (2002).The leadership challenge: How to get extraordinary things done in organizations ( $3^{\text {rd }}$ Ed.). San Francisco, CA:Jossey-Bass.

Kouzes, J. M., \& Posner, B. Z. (2008).The leadership challenge: How to get extraordinary things done in organizations ( $4^{\text {th }}$ ed.). San Francisco, CA:Jossey-Bass.

Kouzes, J. M.\& Posner, B.Z. (2014).Others' Research.Retrieved from http://www.leadershipchallenge.com/Research-section-Others-Research.aspx.

Lewis, M. (1995). Leadership practices inventory [213]. In J.C. Conoley\& J.C. Impara (Eds.), The twelfth mental yearbook (p. 557). Lincoln, NE: Buros Institute of Mental Measurements.

Luthans, F., Youssef, C. M., \&Avolio, B. J. (2006). Psychological capital: Developing thehuman competitive edge. Oxford, UK: Oxford University Press.

Maister, D. (2001). Practice what you preach: What managers must do to create a high achievement culture. New York: Free Press. 
Norman, S., Luthans, B., \& Luthans, K. (2005). The proposed contagion effect of hopefulleaders on the resiliency of employees and organizations. Journal of Leadership \& Organizational Studies, 12(2), 55-64.http://dx.doi.org/10.1177/107179190501200205

Polit, D., \&Hungler, B. (1987).Nursing research: Principles and methods ( $3^{\text {rd }}$ ed.). Lippincott, PA.

Raelin, J. (2006). Does action learning promote collaborative leadership?.Academy ofManagement Learning \&Education, 5(2), 152-158.http://dx.doi.org/10.5465/AMLE.2006.21253780

Resilience Alliance. (2004).Personal Resilience Profile Handbook. Atlanta, GA: Resilience Alliance.

Seeger, M. W., Ulmer, R. R., Novak, J. M., \& Sellnow, T. (2005). Post-crisis discourse andorganizational change, failure, and renewal.Journal of Organizational ChangeManagement,18(1), 78-95.http://dx.doi.org/10.5465/AMLE.2006.21253780

Spector, P. E. (1994). Using self-reported questionnairesin OB research: A comment on the use of a controversial method. Journal of Organizational Behavior, 15(5), 385-392.

Tucker, B. A., \& Russell, R. F. (2004). The influence of the transformational leader.Journal of Leadershipand Organizational Studies, $10(4)$, 103-111.http://dx.doi.org/10.1177/107179190401000408

vanHooft, E., van der Flier, J., \&Minne, M. (2006). Construct validity of multi-source performance ratings: An examination of the relationship of self-, supervisor-, and peer-ratings with cognitive and personality measures. International Journal of Selection and Assessment, 14(1), 67-81.http://dx.doi.org/10.1111/j.1468-2389.2006.00334.x

Werther, Jr., W. B. (2003). Strategic change and leader-follower alignment.Organizational Dynamics, 32(1), 32-45.http://dx.doi.org/10.1016/S0090-2616(02)00136-5

Zagorsek, H., Stough, S.J., \& Jaklic, M. (2004).Analysis of the Reliability of the Leadership Practices Inventory in the Item Response Theory Framework.International Journal of Selection and Assessment, $14(2)$, 180-191.http://dx.doi.org/10.1111/j.1468-2389.2006.00343.x 